\section{High-Throughput RT- PCR Analysis of Multiple Transcripts Using a Microplate RNA Isolation Procedure}

BioTechniques 22:1107-1113 (June 1997)

\begin{abstract}
We have developed a high-throughput, multiplex reverse transcription PCR (RT$P C R)$ assay that is suitable for the analysis of medium- to low-copy cellular RNA transcripts from small numbers of cells $\left(10^{4}\right)$. High throughput was attained by utilizing microplate-based RNA extraction and RTPCR protocols, followed by PCR product visualization of a multiwelled agarose gel, stained with $S Y B R^{\circledR}$ Green I dye. The transcriptional assay was unaffected by solvents
\end{abstract}

(dimethyl sulfoxide and methanol) routinely used in high-throughput drug screens at concentrations required for compound solubilization. Furthermore, it has been used successfully for the investigation of differential mRNA expression levels of tumor necrosis factor alpha $(T N F-\alpha)$ and Interleukin-1 beta $(I L-1 \beta)$ in lipopolysaccharide (LPS)stimulated THP-1 cells (a human monocytic cell line) and the identification of specific $I L-1 \beta$ transcriptional inhibitors.

\section{INTRODUCTION}

The development of a high-throughput in vitro RNA assay would offer the potential to screen thousands of natural products and synthetically derived compounds against numerous therapeutic targets. Conventional methods for monitoring transcriptional regulation require the creation of reporter gene constructs and stably transfected cell lines before assay development, which can take several months. Direct analysis of gene expression by multiplex reverse transcription polymerase chain reaction (RT-PCR) assay would be advantageous, significantly reducing assay development time for new therapeutic targets by permitting the simultaneous analysis of expression levels of several genes in any pharmacologically relevant cell type.

Conventional RNA isolation protocols typically require several hours to process a few samples, involve extensive use of solvents, multiple centrifugation stages and low temperature conditions (1). These rate-limiting stages were overcome by using the QIAGEN ${ }^{\circledR}$ RNeasy ${ }^{\circledR} 96$ microplate-based total RNA isolation system, which works on the principle of vacuum filtration. The RNeasy 96 system was evaluated by multiplex RT-PCR using primers specific for Interleukin-1 beta (IL-1 $\beta$ ), 


\section{Short Technical Reports}

tumor necrosis factor alpha (TNF- $\alpha$ ) and glyceraldehyde-3-phosphate dehydrogenase (GAPDH). The system has proven highly reproducible and suitable for the rapid, high-throughput analysis of compound effects on gene expression and was more conducive to automation than any other system available at the time.

The human monocytic cell line, THP-1, provides a useful model for studying the pathways of macrophage activation. Both IL-1 $\beta$ and TNF- $\alpha$ mRNA can be upregulated in these cells by activation with phorbol myristate acetate (PMA) and lipopolysaccharide (LPS) (2).

The aim of this study was to develop a high-throughput assay capable of detecting compounds that would alter the expression of TNF- $\alpha$ and IL-1 $\beta$ RNA species in THP-1 cells in response to LPS stimulation. This molecular assay system therefore differs from conventional drug screening strategies, which previously have investigated the pleiotropic effects of an individual mediator. The multiplex RT-PCR approach described in this study enables facile detection of specific inhibitors comparing the effects of putative positive compounds on the expression of several transcripts from the same cell source, a process we termed "transcriptional profiling".

\section{MATERIALS AND METHODS}

\section{Cell Culture}

Heat-inactivated fetal calf serum
(HI-FCS; Life Technologies, Paisley, Scotland, UK) and RPMI 1640 tissue culture medium (HyClone Laboratories Europe, Aalft, Belgium) were selected for low LPS levels. THP-1 cells (TIB Accession No. 202; ATCC, Rockville, MD, USA) were cultured in RPMI 1640 medium supplemented with 2 $\mathrm{mM}$ L-glutamine (Life Technologies) and $10 \%$ (vol/vol) HI-FCS. Fifty microliters of cells in log phase growth were seeded into each well of a U-bottomed, 96-well plate (Corning Costar UK, High Wycombe, Bucks, England, $\mathrm{UK})$ at $8 \times 10^{5}$ cells per mL. Lyophilized LPS Salmonella minnesota (Sigma-Aldrich Chemical, Poole, Dorset, England, UK) was reconstituted in RPMI 1640 complete medium, and $50 \mu \mathrm{L}$ were added to each well at a final concentration of $10 \mu \mathrm{g} / \mathrm{mL}$. Fifty microliters of compound in $0.4 \%$ dimethyl sulfoxide (DMSO) were then added, and the plates were incubated at $37^{\circ} \mathrm{C}$ for the appropriate time in $5 \%$ $\mathrm{CO}_{2}$ before RNA isolation.

\section{RNA Extraction}

The RNeasy 96-well plate system (Qiagen Ltd., Dorking, Surrey, England, UK) was used to produce 96 parallel preparations of total RNA from cells grown in microplate wells according to the manufacturer's instructions. RNA was eluted into diethyl pyrocarbonate (DEPC)-treated water and stored at $-80^{\circ} \mathrm{C}$.

\section{RT-PCR Protocol}

Oil-free, first-strand cDNA synthesis
A

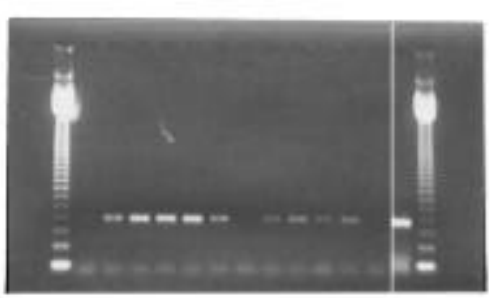

123456789101112131415
B

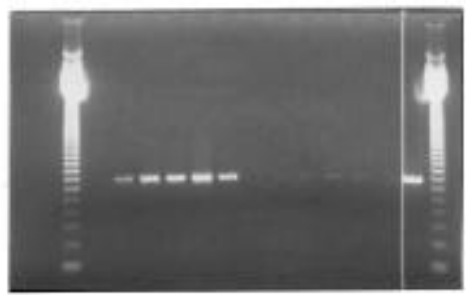

123456789101112131415

Figure 1. Kinetics of LPS induction of IL-1 $\beta$ and TNF- $\alpha$ gene expression. TNF- $\alpha$ (A) and IL- $1 \beta$ (B) RT-PCR amplifications from total RNA isolated from THP-1 cells induced with LPS for the following: $15 \mathrm{~min}$ (lane 2), $30 \mathrm{~min}$ (lane 3), $45 \mathrm{~min}$ (lane 4), $60 \mathrm{~min}$ (lane 5), $120 \mathrm{~min}$ (lane 6) and $180 \mathrm{~min}$ (lane 7). Uninduced THP-1 cells were: $15 \mathrm{~min}$ (lane 8), $30 \mathrm{~min}$ (lane 9), $45 \mathrm{~min}$ (lane 10), $60 \mathrm{~min}$ (lane 11), 120 min (lane 12) and $180 \mathrm{~min}$ (lane 13) after start of experiment. Lane 14 shows positive control. Lanes 1 and 15 show a 123-bp ladder. Gels were prestained with EtdBr and photographed under UV illumination. 
and PCR were performed using an MJ Research Model PTC-200-96V DNA Engine $^{\mathrm{TM}}$ (Genetic Research Instruments, Felsted, Dunmow, Essex, England, UK), 96-well, thin-walled Thermowell ${ }^{\circledR}$ plates (Corning Costar UK) and Microseal ${ }^{\mathrm{TM}}$ A Film (MJResearch, Watertown, MA, USA). First-strand cDNA was synthesized using $8 \mu \mathrm{L}$ of purified RNA as template and the following final concentrations of reagents in a $20-\mu \mathrm{L}$ reaction volume: $12.5 \mathrm{U}$ avian myeloblastosis virus (AMV) Reverse Transcriptase H.C. (Promega, Southampton, England, UK), $5 \mathrm{mM}$ $\mathrm{MgCl}_{2}$ (PE Applied Biosystems, Warrington, Cheshire, England, UK), $80 \mathrm{ng}$ oligo $(\mathrm{dT})_{15} \quad$ (Boehringer Mannheim UK, Lewes, East Sussex, England, UK), 20 U RNase inhibitor, 1× AMV Buffer and $1 \mathrm{mM}$ dNTPs (all from Promega). The RT reaction was carried out at $42^{\circ} \mathrm{C}$ for $30 \mathrm{~min}$ followed by heating at $95^{\circ} \mathrm{C}$ for $10 \mathrm{~min}$ to inactivate the RT.

The PCR amplification was performed using the protocol and final concentrations described below.

\section{Sequence of PCR primers}

GAPDH: forward 5'-TGA-AGG-TCGGAG-TCA-ACG-GAT-TTG-GT-3'; reverse 5'-CAT-GTG-GGC-CAT-GAGGTC-CAC-CAC-3'.

IL-1 $\beta$ : forward 5'-ATG-GCA-GAAGTA-CCT-AAG-CTC-GC-3'; reverse 5'-ACA-CAA-ATT-GCA-TGG-TGAAGT-CAG-TT-3'.

TNF- $\alpha$ : forward 5'-GAG-TGA-CAAGCC-TGT-AGC-CCA-TGT-TGT-AGCA-3'; reverse 5'-GCA-ATG-ATC-CCAAAG-TAG-ACC-TGC-CCA-GAC-T-3'.

\section{PCR protocol}

First cycle: $95^{\circ} \mathrm{C}$ for $5 \mathrm{~min}, 55^{\circ} \mathrm{C}$ for $1 \mathrm{~min}, 72^{\circ} \mathrm{C}$ for $1 \mathrm{~min}$, followed by 25 cycles of $95^{\circ} \mathrm{C}$ for $1 \mathrm{~min}, 55^{\circ} \mathrm{C}$ for 1 $\min , 72^{\circ} \mathrm{C}$ for $1 \mathrm{~min}$ and a final cycle at $72^{\circ} \mathrm{C}$ for $10 \mathrm{~min}$.

For multiplex PCR, a 50- $\mu \mathrm{L}$ reaction volume consisting of $5 \mathrm{U}$ AmpliTaq ${ }^{\circledR}$ (Perkin-Elmer, Norwalk, CT, USA), $1 \mathrm{mM}$ dNTPs (Promega), $1.5 \mathrm{mM}$ $\mathrm{MgCl}_{2}, 1 \times$ amplification buffer (both from PE Applied Biosystems), $5 \mu \mathrm{L}$ first-strand cDNA and 20 pmol of each primer (all obtained from CLONTECH

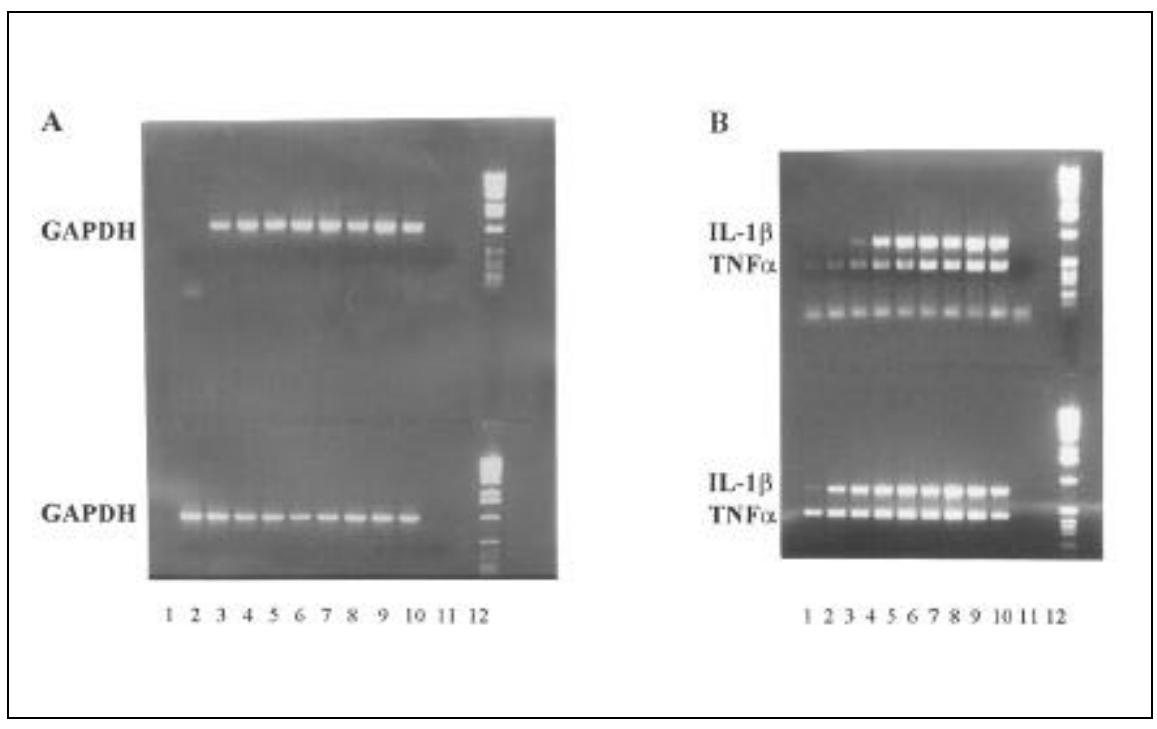

Figure 2. Effects of DMSO and methanol on IL-1 $\beta$, TNF- $\alpha$ and GAPDH levels detected by RTPCR assay. $4 \times 10^{4}$ cells $/$ well were stimulated with $10 \mu \mathrm{g} / \mathrm{mL}$ LPS in the presence of the appropriate concentration of solvent as detailed. GAPDH (A) or IL- $1 \beta$ and TNF- $\alpha$ (B) levels were then measured by RT-PCR. Top: 10, 5, 2.5, 1.25, 0.62, 0.31, 0.16, 0.08 and $0.04 \%$ DMSO (lanes 1-9, respectively); minus DNA control (lane 10); 1-kb ladder (lane 12). Bottom: 10, 5, 2.5, 1.25, 0.62, 0.31, 0.16, 0.08 and 0.04\% methanol (lanes 1-9, respectively); 1-kb ladder (lane 12). Gels were prestained with EtdBr and photographed under UV illumination. 


\section{Short Technical Reports}

Laboratoties, Palo Alto, CA, USA) TNF- $\alpha$, IL- $1 \beta$ and GAPDH were added into each well of a Thermowell plate. The microplates were sealed and the PCRs performed as described above.

\section{Detection of PCR Products with Fluorescence Imaging}

Multiplex PCR products were detected as follows: $5 \mu \mathrm{L}$ of $6 \times$ loading dye (Sigma-Aldrich Chemical) were added to $15 \mu \mathrm{L}$ of PCR product, and $15 \mu \mathrm{L}$ of this sample were then loaded onto a $1.2 \%$ multiwelled agarose gel. The gel consisted of a $30-\times 22-\mathrm{cm}$ casting to which up to 400 samples could be loaded into wells using a multichannel pipet. After electrophoresis in $1 \times \mathrm{TAE}$ buffer $(40 \mathrm{mM}$ Tris-acetate, $1 \mathrm{mM}$
EDTA, pH 8.0), the gel was poststained for $20 \mathrm{~min}$ in $200 \mathrm{~mL}$ of SYBR ${ }^{\circledR}$ Green I (Molecular Probes, Eugene, OR, USA), diluted 1:10000 in $1 \times$ TAE buffer and visualized using a FluorImager ${ }^{\mathrm{TM}} 575$ (Molecular Dynamics Limited, Kemsing, Sevenoaks, Kent, England, UK).

\section{RESULTS AND DISCUSSION}

\section{Microwell RNA Isolation}

RNeasy 96 was the chosen method of RNA extraction best exhibiting the critical parameters required for highthroughput screening, i.e., rapid protocol in a 96-well plate format, minimal solvent requirement and ease to which the procedure could be automated.

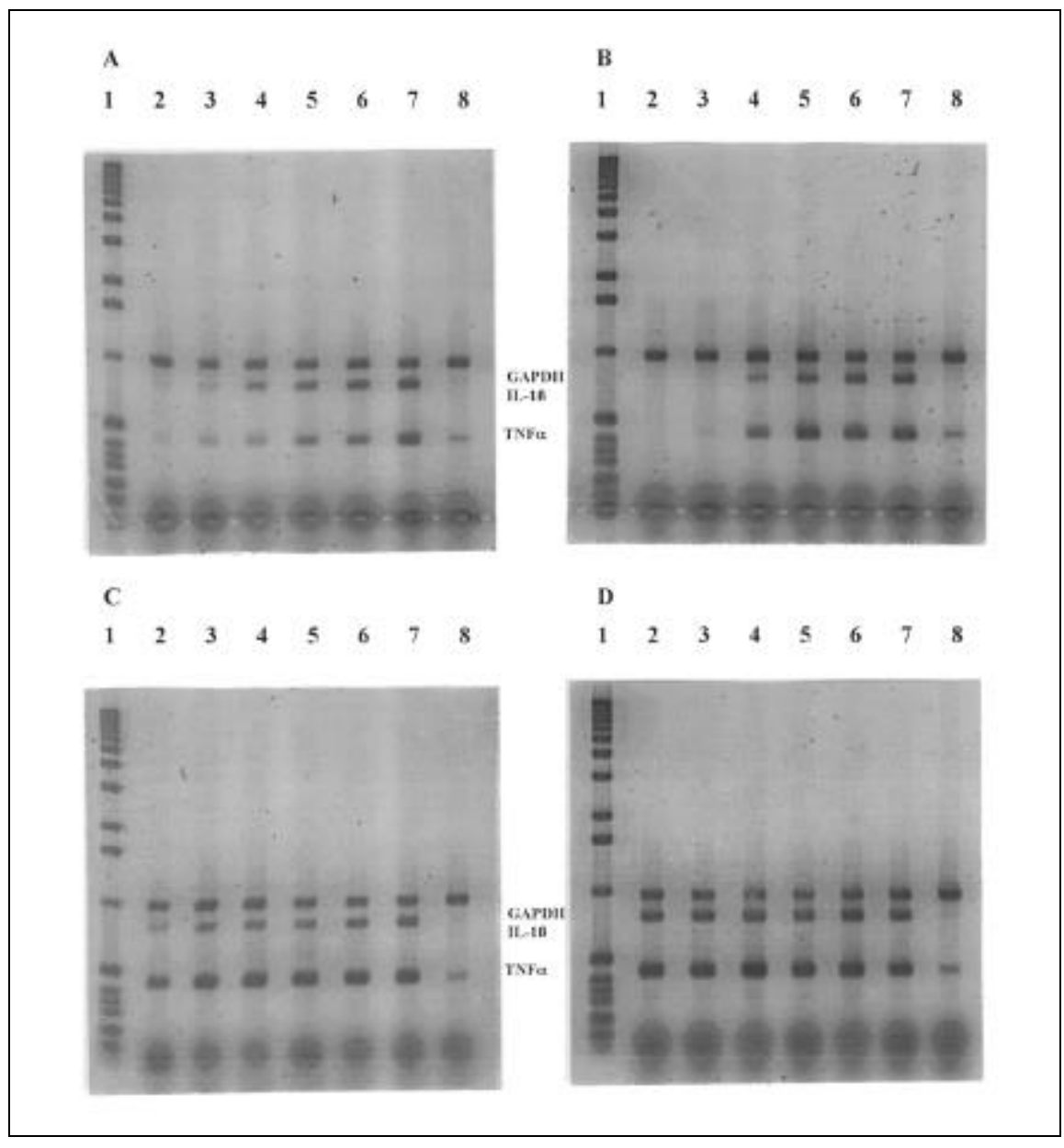

Figure 3. Gel analysis of IL-1 $\beta$ inhibitory compounds. Gel analysis of RT-PCR products from RNA isolated from cells treated with compounds A (Radicicol), B (GR93279A), C (2-methyl sulphonyl-3nitropyrole) and D (SKF86002). 1-kb ladder (lane 1), $20 \mu \mathrm{M}$ (lane 2), $15 \mu \mathrm{M}$ (lane 3), $10 \mu \mathrm{M}$ (lane 4), 5 $\mu \mathrm{M}$ (lane 5) and $2.5 \mu \mathrm{M}$ (lane 6), +LPS positive control (lane 7), -LPS negative control (lane 8). All RTPCR products were run on a multiwelled agarose gel, which was post-stained with SYBR Green and then visualized on a FluorImager 575.
Total RNA extracted by the RNeasy 96 protocol was also found to be stable, as assessed by RT-PCR (i.e., RNA stored for over 6 months at $-80^{\circ} \mathrm{C}$ gave no deleterious effects; data not shown).

\section{Kinetics of LPS-Induced TNF- $\alpha$ and IL-1 $\beta$ Gene Expression in THP-1 Cells}

Using the RT-PCR assay, the kinetics of LPS-induced TNF- $\alpha$ (Figure 1A) and IL-1 $\beta$ (Figure 1B) gene expression were investigated. The expression of both transcripts is upregulated after LPS stimulation, and a significant increase can be seen at $30 \mathrm{~min}$, before peaking at approximately $2 \mathrm{~h}$ and declining by $3 \mathrm{~h}$. All further analysis was performed on total RNA, which was isolated $2 \mathrm{~h}$ after induction.

\section{Effect of Solvents on RT-PCR Assay}

DMSO is routinely used for compound solubilization and methanol for the extraction of metabolites from natural products. These solvents were tested to identify any adverse effects on either RNA extraction or on the RTPCRs. THP-1 cells were stimulated with LPS in the presence of varying concentrations of solvent, and the effect on IL- $1 \beta$, TNF- $\alpha$ and GAPDH gene expression was evaluated by RT-PCR. DMSO reduced the amount of TNF- $\alpha$ and IL- $1 \beta$ message at concentrations of greater than $0.6 \%$ and $1.25 \%$, respectively (Figure 2B). Methanol had a lesser effect, only significantly reducing the amount of IL- $1 \beta$ message at a concentration of $5 \%$ and having a minimal effect on the TNF- $\alpha$ transcript levels at $10 \%$ (Figure 2B). DMSO and methanol are routinely used at a concentration of $0.04 \%$, which would have no effect on the expression of the three transcripts described. Solvent effects on GAPDH message were negligible at the concentrations tested (Figure 2A), probably because of the high constitutive levels of this mRNA species. In retrospect, a medium-to-low-copy housekeeping gene such as human transferrin receptor may have proved a more suitable toxicity control; GAPDH being so highly expressed may only suffice as a marker of highly toxic or lytic compounds. 


\section{Quantification of DNA with SYBR Green I Dye}

Conventional visualization of agarose gels by post-staining with ethidium bromide $(\mathrm{EtdBr})$ has a detection limit of between 0.4 and $0.9 \mathrm{ng}$ of DNA (data not shown). SYBR Green I poststaining followed by visualization of the gel on a FluorImager increases the sensitivity of detection by 16 -fold (data not shown), thereby increasing the speed and sensitivity of the assay, as less PCR cycles are required. The FluorImager software (ImageQuant ${ }^{\mathrm{TM}}$; Molecular Dynamics) can be used to quantify the intensity of bands in agarose gels. By ensuring that the PCR conditions are appropriately optimized (the number of cycles used are within the exponential phase of amplification) and that the amount of SYBR Green-labeled PCR product to be detected is within the linear range of detection of the FluorImager, we were able to obtain a semiquantitative readout.

\section{Effects of Known Inhibitors on IL-1 $\beta$ mRNA Expression}

Four putative IL-1 $\beta$ transcriptional inhibitors, identified from an in-house reporter gene assay were used to further evaluate the RT-PCR assay (Figure 3). Compounds A (Radicicol) and B showed no inhibitory effect on GAPDH transcript but reduced the levels of both IL- $1 \beta$ and TNF- $\alpha$ transcripts at concentrations exceeding 5 and $10 \mu \mathrm{M}$, respectively (Figure 3, A and B), implying that both compounds may be acting at a point common to both signal transduction pathways. Radicicol is a fungal metabolite, which is a specific protein tyrosine kinase inhibitor of $\mathrm{P} 60^{\mathrm{v}-\mathrm{src}}$ (3).

Compound $\mathrm{C}$, which had an $\mathrm{IC}_{50}$ of $4 \mu \mathrm{M}$ in an IL-1 reporter gene assay and $20 \mu \mathrm{M}$ in secondary cellular as- says, selectively reduced the concentration of IL- $1 \beta$ message at $20 \mu \mathrm{M}$ in the RT-PCR assay (Figure 3C). Compound D (SKF86002) is a pyridylimidazole that has also been identified by SmithKline Beecham as an inflammatory inhibitor of IL-1 biosynthesis in vitro (4) by acting at the translational level (7). At $20 \mu \mathrm{M}$, this compound had no effect on any of the three transcripts, providing further evidence that this is a translational inhibitor of IL-1 (Figure 3D).

\section{CONCLUSIONS}

In summary, the RNeasy RNA extraction high-throughput screening system is rapid ( $\leq 40 \mathrm{~min}$ to isolate 96 samples), can be performed at room temperature and has the potential for the isolation of over five hundred RNA samples a day from as few as $10^{4}$ cells/ well. The effects of 96 compounds on 
several transcripts can be observed within a day and a half, most of this time being "non-hands-on" time; i.e., for incubation and thermal cycling. The efficiency of RNeasy isolation combined with the sensitivity of RT-PCR allows the detection of medium-to-lowcopy genes, i.e., several transcripts per cell as determined by experiments with RNA mimics (data not shown). Multiplex RT-PCR allows "Transcriptional Profiling", i.e., the ability to profile the effects of compounds on several transcripts from one cell source. This allows the differential expression of genes occuring within cells to be visualized, thus resulting in a more confident means of distinguishing between transcriptional inhibitors and toxins detrimental to cell growth. Apart from increased throughput achieved by screening multiple targets at a time, multiplex PCR has the added advantage of allowing specific and toxic compounds to be identified at an early stage, thus increasing the rate at which they can be processed or discarded, respectively.

In conclusion, we have developed a rapid, sensitive and efficient method of analyzing transcriptional events and subsequent modulation of these genes after controlled stimulation. The system has the power to analyze the effects of hundreds of compounds on more than one transcriptional event and identify putative modulators within a couple of days. Once automated, this throughput could be increased even further.

\section{REFERENCES}

1.Chomczynski P. and N. Sacchi. 1987. Singlestep method of RNA isolation by acid guanidinium thiocyanate-phenol-chloroform extraction. Anal. Biochem. 162:156-159.

2.Cochran, F.R. and M.B. Finch-Arietta. 1989. Regulation of interleukin-1 $\beta$ and tumour necrosis factor secretion by the human monocytic leukaemic cell line, THP-1. Agents Actions 27:271.

3.Kwon J.H., M. Yoshida, Y. Fukui, S. Horinouchi and T. Beppu. 1992. Potent and specific inhibition of $\mathrm{P} 60^{\mathrm{v}-\mathrm{src}}$ protein kinase both in vivo and in vitro by Radicicol. Cancer Res. 52:6926-6930.

4.Lee, J.C., J.T. Laydon, P.C. McDonnell, T.F. Gallagher, S. Kumar, D. Green, D. McNulty, M.J. Blumenthal et al. 1994. A protein kinase involved in the regulation of inflammatory cytokine biosynthesis. Nature 372:739-746.
5.Oppenheim, J.J., K. Matsushima, T. Yoshimura and E.J. Leonard. 1987. The activities of cytokines are pleiotropic and interdependent. Immunol. Letts. 16:179.

6.Reinecker, H.C., M. Steffen, T. Witthoeft, I. Pflueger, S. Schreiber, R.P. MacDermott and A. Raedler. 1993. Enhanced secretion of TNF- $\alpha$, IL- 6 and IL- $1 \beta$ by isolated lamina propia mononuclear cells from patients with ulcerative colitis and Crohn's disease. Clin. Exp. Immunol. 94:174-181.

7.Young, P., P. McDonnel, D. Dunnington, A. Hand, J. Laydon and J. Lee. 1993. Pyridinyl imidazoles inhibit IL-1 and TNF production at the protein level. Agents Actions 39:67-69.

8.Zangerle, P.F., D. De Groote, M. Lopez, R.J. Meulemen, Y. Vrindts, F. Fauchet, I. Dehart, M. Jadoul, D. Radoux and P. Franchimont. 1992. Direct stimulation of cytokines in whole blood. II: Application to rheumatoid arthritis and osteoarthritis. Cytokine 4:568675 .

Authors S. Su and R.G. Vivier both contributed equally to this publication. Thanks to Don Wallace, Doug Montgomery and Frank Van Middlesworth for their assis- tance. Address correspondence to Richard George Vivier, Unit of Immunology, Glaxo Wellcome Research and Development, Medicines Research Centre, Gunnels Wood Road, Stevenage, Hertfordshire, England, UK.

Received 26 April 1996; accepted 19 November 1996.

S. Su, R.G. Vivier, M.C. Dickson, N. Thomas', M.K. Kendrick $^{1}$, N.M. Williamson', J.G. Anson ${ }^{1}$, J.G. Houston and F.F. Craig Glaxo Wellcome Research and Development

Stevenage, Herts

${ }^{1}$ Amersham International

Cardiff, England, UK 